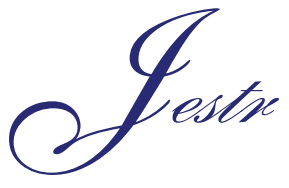

Journal of Engineering Science and Technology Review 3 (1) (2010) 14-22

JOURNAL OF

Engineering Science and

Technology Review

Research Article

\title{
Effects of pollution in River Krishni on hand pump water quality
}

\author{
K. Dhakyanaika* and P. Kumara
}

Department of Civil Engineering, Indian Institute of Technology Roorkee, Roorkee- 247 667, Uttarakhand, India.

Received 10 July 2009; Accepted 29 January 2010

\begin{abstract}
River Krishni is highly polluted. The investigation was "to study the effect of pollution in River Krishni on the quality of groundwater abstracted through shallow and deep hand pumps placed in the close vicinity of River Krishni”. One such affected Village Chanedna Maal was selected for the study. Water samples were analyzed in terms of physical, chemical and bacteriological water quality parameters. Range of values of conductivity $(1040-2770 \mu \mathrm{S} / \mathrm{cm})$, TOC $(27.79-1365.1$ $\mathrm{mg} / \mathrm{L}), \mathrm{UV}$ absorbance at $254 \mathrm{~nm}\left(0.281-10.34 \mathrm{~cm}^{-1}\right)$, color $(1510-5200 \mathrm{CU})$, and COD $(15.82-1062 \mathrm{mg} / \mathrm{L})$ indicated presence of significant amount of pollution / organics in the river water, total coliform (16x102-46x106 MPN/100mL) and fecal coliform $(16 \times 102-24 \times 106 \mathrm{MPN} / 100 \mathrm{~mL})$. In case of deeper India Mark-II hand pumps conductivity was found to range from $443-755 \mu \mathrm{S} / \mathrm{cm}$, TOC $(0.226-9.284 \mathrm{mg} / \mathrm{L})$, UV absorbance $\left(0.0-0.118 \mathrm{~cm}^{-1}\right)$, colour $(0.0-119 \mathrm{CU})$, COD $(9.0-113 \mathrm{mg} / \mathrm{L})$ and MPN $(0.0-93 \times 101 / 100 \mathrm{~m} \mathrm{~L})$. While in case of shallower hand pumps conductivity $(441-1609 \mu \mathrm{S} /$ $\mathrm{cm})$, TOC $(0.015-68.82 \mathrm{mg} / \mathrm{L})$, UV absorbance $\left(0.0-1.094 \mathrm{~cm}^{-1}\right)$, colour $(4.0-560 \mathrm{CU}), \mathrm{COD}(9.72-163 \mathrm{mg} / \mathrm{L})$ and MPN $(0.0-15 \times 102 / 100 \mathrm{~mL})$. Hand pumps abstracting water from shallow and deep unconfined aquifers have been found to deliver polluted water in terms of color, organics and coliform bacteria. As the hand pumps are the only source of water supply in Village Chandena Maal, pollution of the groundwater has adversely affected the day to day life of its 3000 residents.
\end{abstract}

Keywords: Water supply, River Krishni, Hand pumps, Water quality, Laboratory experiments / measurements, India.

\section{Introduction}

India has large number of rivers which have been nurturing its vast fertile lands. Due to the urbanization and industrial development stress on the environment is well recognized. Most of the cities/towns situated on the banks of the rivers, discharge their untreated/ partially treated/ treated wastewaters into the rivers. It is estimated that community waste from human activities accounts for four times as much wastewater as industrial effluents, most of which is discharged untreated/ partially treated into the water courses in India [1]. Surface waters intended to be used for the drinking purposes can vary markedly in their organic and inorganic contents. High levels of variation occur in the range of water quality parameters such as turbidity, color, UV- absorbance etc.

Groundwater is an important source of water for domestic, industrial and agricultural purposes. It is estimated that more than $90 \%$ of the rural population uses groundwater for domestic purposes [2].

Scope of the study was follows: Some of the industries Major/some portion of their treated/untreated/partially treated wastewaters are discharged in the River Krishni either on regular basis or occasionally. The river water in the area of the study is coloured,

\footnotetext{
* E-mail address: dhakuiitr2007@gmail.com

ISSN: 1791-2377 (C) 2010 Kavala Institute of Technology. All rights reserved.
}

polluted and odours. It cannot be classified a healthy fresh water stream. Such polluted surface water is likely to pollute ground water resources along its path of flow. Efforts have been made in the present investigation to study the interaction of polluted water of River Krishni and ground water in and around Village Chandena Maal. Scope of the work included the following: To assess the water quality of River Krishni around Village Chandena Maal during the non monsoon periods when there is flow in it and when there is no flow in it. (a) To characterize wastewaters from the major drains known to discharge the effluents from the industries in the area around Chandena Maal into the River Krishni. (b) To assess water quality of ground water being abstracted through shallow and deep hand pumps in the Village Chandena Maal around River Krishni.

Ground water is the major source of water supply for drinking and other purposes in the rural areas of India. In many parts of India, the available water for drinking purposes, groundwater or municipal water sourced from groundwater, is rendered nonpotable due to the presence of high concentrations of fluoride and other constituents. Dental and skeletal fluorosis is one of the serious health problems prevalent in 150 districts of 17 States of India. It is emerging as a social problem as well in many villages of northern India [3]. In comparison to most groundwater sources, alluvial aquifers that are hydraulically connected to rivers are typ- 
ically easier to exploit (shallow) and more highly productive for drinking water supplies [4].

Lakes and rivers have been and continue to be the major sources of water supply. The water quality is influenced by the strata through which incoming groundwater travels, as well as by the activities in the catchment affecting surface run-off to the lake. The surface water, which is vulnerable to pollution, cannot be used without treatment.

Groundwater often can be used without treatment. However, limited groundwater resources, decreasing level of groundwater due to over-abstraction and increasing cost of pumping, are not in tune with the environmental obligations for future generations [5].

The water quality of river Krishni has been studied at 8 sampling points fixed at 70 kilometers stretch. The river received about 50 to 67 cusec, of domestic and industrial waste water via three waste water channels containing high amount of total solids, dissolved solids, suspended solids, bio-chemical oxygen demand (BOD), chemical oxygen demand (COD), albuminoid nitrogen, ammonical nitrogen, nitrate nitrogen, sulphate, phosphate and chlorides. These waste contents of the waste water have changed the characteristics of the river water to great extent [5].

The exploitation of groundwater by means of boreholes for supplying small user groups and rural communities with water has been widely applied in certain parts of the world for several decades. In recent years this practice has spread all over the globe and hundreds of thousands of boreholes have been drilled to tap low-yield aquifers. It is evident that such boreholes require pumps for lifting the water. [7].

\section{Study area}

River basin of Krishni is a part of Indogangetic plain. Due to its strategic geological location, river Krishni plays a prominent role in the economy of the Western Uttar Pradesh. It passes through three major industrially and agriculturally advanced districts of UP viz. Saharanpur, Muzaffar Nagar and Meerut. From Pargana Rampur in the district Saharanpur, it enters Muzaffar Nagar district at the village Chandena Maal, five kilometer north of Jalalabad. River Krishni ultimately joins river Hindon at Barnava in District Meerut and empties its pollution load, which in turn confluences with River Yamuna at Tilwara in District Ghaziabad. The length of the river is about $150 \mathrm{kms}$. It flows between two bigger Rivers Yamuna and Hindon almost parallel to both. Since its catchment area is in the form of a narrow strip, total catchment area is only approximately 2500 sq.km.

River Krishni is a typical example of the water courses of Western UP which receive domestic and industrial effluents throughout their lengths. There are number of large, medium and small-scale industries such as sugar, distillery, card-board and food-products etc. in the catchment of River Krishni which discharge their treated or untreated wastewaters to the river. Water level in the river varies a lot due to the seasonal nature of some of these industries. Water looks coloured, and smells a lot. Whenever even a slight wind blows from river side towards the adjoining village, entire village environment gets filled with the unacceptable odour.

The Village Chandena Maal is situated in block Thana Bhawan, Teshil Shamli of District Muzaffar Nagar in Western Uttar
Pradesh. It is about $8 \mathrm{kms}$ from Thana Bhawan, about $28 \mathrm{kms}$ from Shamli and about $45 \mathrm{kms}$ from Muzaffar Nagar. The village is about $15 \mathrm{kms}$ south of Nanauta, which has many industries. It is situated close to Delhi- Saharanpur highway.

The village topography is almost plain with a difference of $3.685 \mathrm{~m}$ in the highest and lowest ground levels [8]. The populations of village Chandena Maal in Census year 2001 was 2769 and at present in 2009 is estimated to be around 3200. The main occupation of villagers is agriculture. Wheat and sugar cane are the main crops in the area. The village has power supply for only about 8 hours per day. There is one primary school, one Shishu Mandir and one junior high school in the village. Domestic sewage and storm water flows through surface drains constructed on both sides of the narrow village streets which ultimately flow outside the village and in many cases into the River Krishni.

At present the inhabitants meet their daily requirement through shallow and deep (India Mark-II) hand pumps. There are approximately 50 hand pumps, out of which about 35 are shallow and remaining about 15 are deep hand pumps. Water from most of the hand pumps in the village is coloured. Although it varies a lot from very light yellow to dark brown from one hand pump to other depending upon depth of the hand pump and its distance from the river. In general, water of shallow hand pumps has been found to have darker color compared to deep hand pumps. Shallow hand pumps in the village have depths ranging from $15-35 \mathrm{~m}$ while deeper ones are $35-55 \mathrm{~m}$. At present a water supply scheme based on a deep tube well $(\sim 130 \mathrm{~m})$ is under construction.

\section{Materials and methods}

The objective of the present work was to study the effect of pollution in River Krishni on the quality of water from hand pumps.

On the basis of a preliminary study sampling locations were selected in the study area. The selected sampling locations could be categorized as given below:

(a) On the polluted and relatively unpolluted stretch of the river,

(b) On the sources of water supply: Shallow and deep hand pumps, and natural pond,

(c) On the major waste water drains coming from different industries and discharging into the river.

Sampling locations are shown in Fig.1. Many of the minor wastewater drains were not monitored. During the study a deep tube well $(\sim 130 \mathrm{~m})$ was constructed in the village but it could not be made functional as pipe lines were not laid during the course of the study. Water from the tube well was not available for the analysis. It is expected that tube well will start delivering water by December, 2009. Total cost of the upcoming project is $\sim$ Rs 50 lacs.

Water samples from upstream and downstream of River Krishni, hand pump(s) located in the villages Chandena Maal, Banhera Khemchand and Kachrai and from drains carrying industrial effluents towards the River Krishni were collected four times for the analysis of water quality parameters.

Water samples from each sampling point were collected in two plastic bottles of one liter each. Simultaneously samples for bacteriological analyses were collected in sterilized, high-densi- 
ty, glass bottles covered with aluminum foils. The samples were transported to the Environmental Engineering Laboratory, Department of Civil Engineering, IIT Roorkee. Samples were analyzed for physico-chemical and microbiological parameters (viz. temperature, $\mathrm{pH}$, DO, conductivity, TDS, TOC, colour, COD, BOD, UV absorbance, turbidity, major cations, major anions, nitrate, TS, coliforms and heavy metals) as per the procedures prescribed in Standard Methods [9].

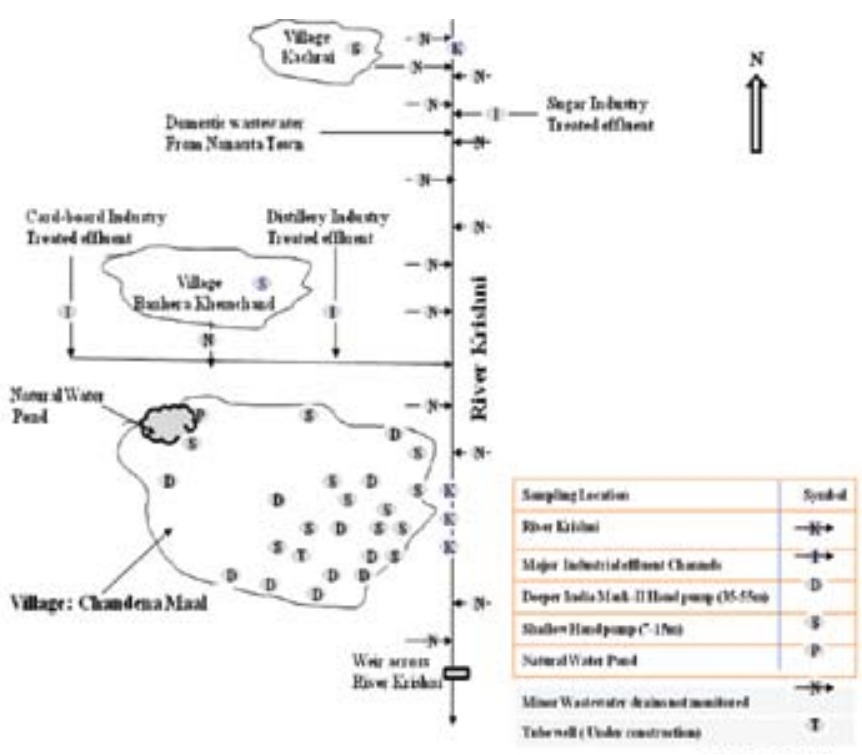

Figure 1. Line diagram of area around village Chandena Maal showing sampling points.

The sampling program was divided in following two phases:

Phase 1.

When industries were working (i.e. there was flow in the river Krishni): Period of sampling in the months of November \& December, 2008 and February, 2009. During this period of sampling sugar, distillery, card board and many other industries were working.

\section{Phase 2.}

When Industries were not working (i.e. there was no flow in the river Krishni): Period of sampling in the month of May, 2009. During fifth sampling sugar, distillery and card board industries were not working.

\section{Results and discussions}

\subsection{Soil strata: Viilage Chandena Maal}

Village Chandena Maal is situated on the left bank of the River Krishni. At present villager's abstract ground water using about 50 shallow and 25 deep hand pumps for their daily requirements of water. In Chandena Maal, generally the depths of shallow hand pumps are in the range of 15-35 $\mathrm{m}$ while the depths of the deeper IM-II hand pumps are 35-55 m. In and around Village Chandena Maal, both the water of River Krishni and ground water pumped out by the hand pump(s) are polluted. In general, water of the shallow hand pumps in the village is darker in colour (yellowish) compared to the IM-II hand pumps. During the course of this study a deep tube well of about $130 \mathrm{~m}$ depth was constructed in the village to meet out the requirements of the water supply. In the tube well the strainers are placed at three levels i.e. depths of 66.19-70.44 $\mathrm{m}, 85.31-97.27 \mathrm{~m}$ and 103.16-115.20 $\mathrm{m}$ in the water bearing layers of fine to medium sand. Based on the soil strata charts prepared during the construction of the twenty one IM -II hand pumps from 1998 to 2008 and the tube well in 2009, the soil strata at the Village Chandena Maal and the cross-sections of shallow and deep hand pumps and the newly constructed tube well are also shown in the Fig. 2 The three water abstraction devices tap water bearing strata at different levels. The hydrogeology reveals occurrence of alternate layers of the clay and sand. Aquifer broadly behaves as a single bodied aquifer down to the depth of approximately $100 \mathrm{~m} \mathrm{bgl} \mathrm{(metre} \mathrm{below} \mathrm{ground} \mathrm{level)} \mathrm{as} \mathrm{the} \mathrm{clay}$ layers laterally pinch out.

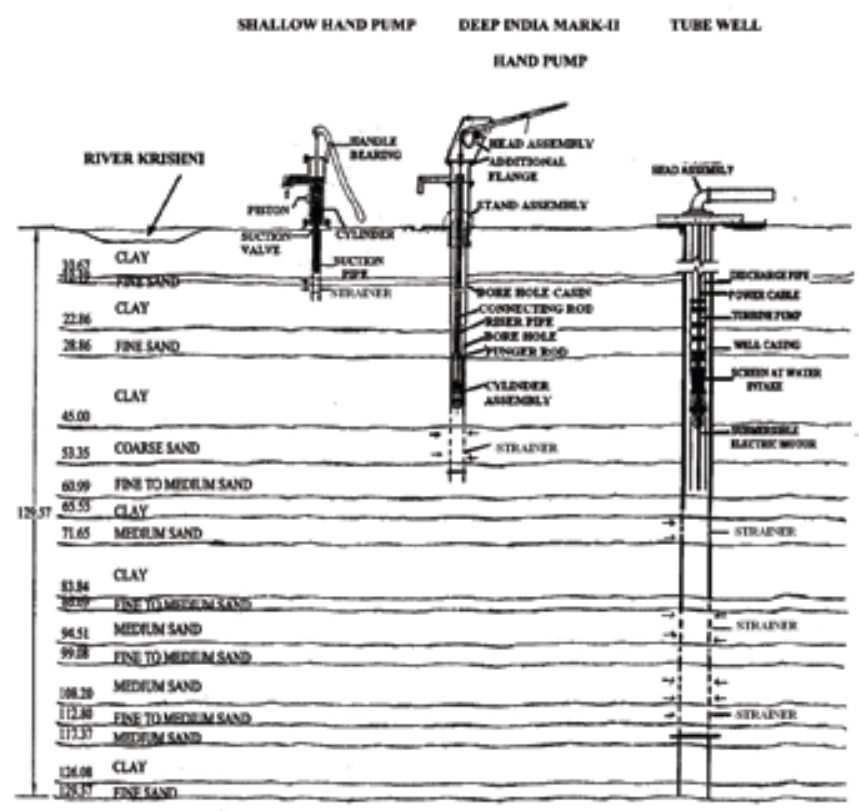

Figure 2. Soil Strata: Village Chandena Maal.

River Krishni travels between Rivers Ganga and Yamuna and the area around Village Chandena Maal lies in the Central Ganga Plain, a highly fertile track of Western Uttar Pradesh. The area is part of the Central Ganga basin, well endowed with the groundwater resources; however, overexploitation has created adverse impact on the groundwater regime.

Aquifers of Quaternary age form the major source of irrigation and municipal water supplies. The River Krishni is effluent throughout its course. Ground water resources of the area lying between the River Krishni on the east and the River Yamuna on the west have been evaluated by Ahmed and Umar (2008) [10]. A network of 28 observation wells was established. Because the rainfall is restricted, repeat measurements of water levels were carried out in the months of June and November 2004, as water level is maximum in the month of June and minimum in the month of November for a specific year. Twenty litho logs of boreholes were used by Ahmed and Umar (2008) [10] to prepare various hydro geological cross sections. Geologically, the area is underlain by alluvial deposits of Quaternary age consisting of older and younger alluviums. The latter is confined to the river channel or in the low-lying areas. Younger alluvium is generally inundated by 
floods during monsoon. The alluvium in Krishni-Yamuna interfluves consists of alternate beds of sand and clay with occasional interbeds of calcareous concretion, locally known as kankar.

Four distinct groups of permeable granular zones were identified in the depth range of 1-185 m, 115-235 m, 235-329 $\mathrm{m}$ and 355-488 m below ground level (bgl), separated by three impermeable horizons (Bhatnagar et al. 1982). There is alternate zonation of granular and clay beds. The top clay layer persists throughout the study area.

The clay beds pinch out at regional scale and consequently the aquifer system behaves as a single bodied aquifer to the depth of about $100 \mathrm{~m}$ bgl. Section A-B drawn along E-W direction shows the persistence of surface clay throughout the area, followed by the granular zone ranging in thickness from $8 \mathrm{~m}$ in the east to $15 \mathrm{~m}$ in the west. The second granular bed occurs in depth range of $25-80 \mathrm{~m} \mathrm{bgl}$ which is $30-45 \mathrm{~m}$ in the water table in the shallow aquifer is unconfined in nature. The premonsoon depth to the water level varies between 5 and $16.5 \mathrm{~m} \mathrm{bgl} \mathrm{[10].}$

\subsection{Water quality parameters}

Water samples of River Krishni, major industrial wastewater drains, a natural pond and hand pump(s) in and around Village Chandena Maal were analyzed for physico-chemical and microbiological parameters (viz. temperature, $\mathrm{pH}$, DO, conductivity, TDS, TOC, colour, COD, BOD, UV-absorbance, turbidity, major cations, major anions, nitrate, TS, coliforms and heavy metals) as per the procedures prescribed in Standard Methods [9] for five.

The ranges of the analysis and results of various physicochemical and microbiological parameters are given in Table. 1 and Table.2.

Table 1. Range of Water Quality Parameters: Phase-1 (When Industries were working)

\begin{tabular}{|c|c|c|c|c|c|}
\hline S.No & Parameters & $\begin{array}{c}\text { Effluent } \\
\text { channels } \\
\text { (min. - max.) }\end{array}$ & $\begin{array}{c}\text { River } \\
\text { (min. - max.) }\end{array}$ & $\begin{array}{l}\text { Natural } \\
\text { Water } \\
\text { pond }\end{array}$ & $\begin{array}{c}\text { SHPs } \\
\text { (min.- max.) }\end{array}$ \\
\hline 1 & $\mathrm{pH}$ & $5.39-8.05$ & $5.2-7.02$ & 6.62 & $6.78-7.62$ \\
\hline 2 & $\begin{array}{l}\text { Conductivity } \\
(\mu \mathrm{S} / \mathrm{cm})\end{array}$ & $811-4970$ & $1040-2770$ & 875 & $441-1609$ \\
\hline 3 & TDS (mg/L) & $489-2982$ & $624-1666$ & 526 & $265-966$ \\
\hline 4 & $\begin{array}{l}\text { Turbidity } \\
\text { (NTU) }\end{array}$ & $11.4-87.4$ & $49.2-157$ & 37 & $0.414-76.8$ \\
\hline 5 & Colour (CU) & $249-12750$ & $1510-5200$ & 334 & $4.0-560$ \\
\hline 6 & TOC (mg/L) & $9.02-2383$ & $27.79-1365.1$ & 5.774 & $0.015-68.82$ \\
\hline 7 & $\begin{array}{l}\text { UV-absorbance } \\
\left(\mathrm{cm}^{-1}\right)\end{array}$ & $0.236-1.05$ & $0.281-10.34$ & 0.434 & $0.0-1.094$ \\
\hline 8 & COD (mg/L) & $36.69-862$ & $15.82-1062$ & 67.417 & $9.72-163$ \\
\hline 9 & $\mathrm{BOD}(\mathrm{mg} / \mathrm{L})$ & $14.67-521.28$ & $6.35-636.55$ & 26.966 & $3.99-94.05$ \\
\hline 10 & $\begin{array}{l}\text { Total hardness } \\
(\mathrm{mg} / \mathrm{L})\end{array}$ & $1040-4500$ & $1120-8600$ & 1160 & $208-1440$ \\
\hline 11 & $\begin{array}{l}\text { Total coliform } \\
\text { (MPN/100mL) }\end{array}$ & $43-24 \times 10^{3}$ & $16 \times 10^{2}-46 \times 10^{6}$ & $11 \times 10^{3}$ & $0.0-15 \times 10^{2}$ \\
\hline 12 & $\begin{array}{l}\text { Fecal coliform } \\
(\mathrm{MPN} / 100 \mathrm{~mL})\end{array}$ & $43-9 \times 10^{3}$ & $16 \times 10^{2}-24 \times 10^{6}$ & $11 \times 10^{3}$ & $0.0-15 \times 10^{2}$ \\
\hline
\end{tabular}

SHP -Shallow Hand pump; IM-II HP - India Mark-II Hand pump

\subsubsection{Phase 1. When Industries were Working (i.e. There was Flow in the River Krishni).}

During this period of sampling sugar, distillery, card board and many other industries were working around Chandena Maal. The results of the analysis are given in Table. The results broadly indicate that the quality of the water varies considerably from one location to the other.

Spatial and temporal variation of TDS, conductivity, colour, turbidity, COD, UV-absorbance, BOD, TOC, total coliform and fecal coliform at different sampling points is shown in Fig.3 -Fig.16. The range of values of TDS, conductivity, colour, turbidity, COD, UV-absorbance, BOD, TOC, total coliform and fecal coliform for different samples were: river water (624-1666 mg/L and 1040-2770 $\mu \mathrm{S} / \mathrm{cm}),(1510-5200 \mathrm{CU}),(49.2-157 \mathrm{NTU}),(15.82-1062 \mathrm{mg} / \mathrm{L})$, $\left(0.281-10.34 \mathrm{~cm}^{-1}\right),(6.35-636.55 \mathrm{mg} / \mathrm{L}),(27.79-1365.1 \mathrm{mg} / \mathrm{L})$, $\left(16 \times 10^{2}-46 \times 10^{6} \mathrm{MPN} / 100 \mathrm{~mL}\right)$ and $\left(16 \times 10^{2}-24 \times 10^{6} \mathrm{MPN} / 100\right.$ $\mathrm{mL})$, Sallow Hand Pumps (265-966 mg/L and 441-1609 $\mu \mathrm{S} / \mathrm{cm})$, (4-560 CU), (0.414-76.8 NTU), (9.72-163 mg/L), $\left(0-1.094 \mathrm{~cm}^{-}\right.$ 1), (3.99-94.05 mg/L), (0.015-68.82 mg/L), (0-15x10² MPN/100 $\mathrm{mL}),\left(0-15 \times 10^{2} \mathrm{MPN} / 100 \mathrm{~mL}\right)$, India Mark-II Hand Pumps (265$453 \mathrm{mg} / \mathrm{L}$ and $443-755 \mu \mathrm{S} / \mathrm{cm}),(0-119 \mathrm{CU}),(0.294-7.12 \mathrm{NTU})$, $(9-113 \mathrm{mg} / \mathrm{L}),\left(0-0.118 \mathrm{~cm}^{-1}\right),(5.53-67.8 \mathrm{mg} / \mathrm{L}),(0.226-9.284$ $\mathrm{mg} / \mathrm{L}),\left(0-93 \times 10^{1} \mathrm{MPN} / 100 \mathrm{~mL}\right),(0-90 \mathrm{MPN} / 100 \mathrm{~mL})$, natural water pond $(526 \mathrm{mg} / \mathrm{L}$ and $875 \mu \mathrm{S} / \mathrm{cm}),(334 \mathrm{CU}),(37 \mathrm{NTU})$, $(67.417 \mathrm{mg} / \mathrm{L}),\left(0.434 \mathrm{~cm}^{-1}\right),(26.966 \mathrm{mg} / \mathrm{L}),(5.774 \mathrm{mg} / \mathrm{L}),\left(11 \times 10^{3}\right.$ MPN/100 mL), (11x10 MPN/100 mL), effluent channels (489$2982 \mathrm{mg} / \mathrm{L}$ and $811-4970 \mu \mathrm{S} / \mathrm{cm}),(249-12750 \mathrm{CU}),(11.4-87.4$ NTU), (36.69-862 mg/L), (0.236-1.05 cm $\left.\mathrm{cm}^{-1}\right), \quad(14.67-521.28$ $\mathrm{mg} / \mathrm{L}),(9.02-2383 \mathrm{mg} / \mathrm{L}),\left(43-24 \times 10^{3} \mathrm{MPN} / 100 \mathrm{~mL}\right),\left(43-9 \times 10^{3}\right.$ $\mathrm{MPN} / 100 \mathrm{~mL}$ ) respectively.

4.2.2 Phase 2. When Industries were not working (i.e. there was no flow in the river Krishni): Period of sampling - May, 2009.

During this period of sampling sugar, distillery, card board and many other industries were not working around Chandena Maal. The results of the analysis are given in Table.2. the results broadly indicate that the quality of the water varies considerably from one location to the other.

Spatial and temporal variation of TDS, conductivity, colour, turbidity, COD, UV-absorbance, BOD, TOC, total coliform and fecal coliform at different sampling points is shown in Fig.3-Fig The values of TDS, conductivity, colour, turbidity, COD, UV-absorbance, BOD, TOC, total coliform and fecal coliform for different samples were: river water $(1296 \mathrm{mg} / \mathrm{L}$ and $2160 \mu \mathrm{S} / \mathrm{cm}),(1520 \mathrm{CU}),(50.8$ NTU), (265.94 mg/L), (2.301 cm $\left.\mathrm{cm}^{-1}\right),(157.94 \mathrm{mg} / \mathrm{L}),(40.09 \mathrm{mg} / \mathrm{L})$, (43MPN/100 mL) and (23MPN/100 mL), Sallow Hand Pumps (273-971 mg/L and 455-1528 $\mu \mathrm{S} / \mathrm{cm}),(01-395 \mathrm{CU}),(0.294-11.7$ NTU), (3.23-26.6 mg/L), (0.001-1.053 cm $\left.\mathrm{cm}^{-1}\right),(0-48.25 \mathrm{mg} / \mathrm{L})$, (9.143-30.65 mg/L), (<3-150 MPN/100 mL), (<3-150 MPN/100 $\mathrm{mL})$, India Mark-II Hand Pumps (273-444 mg/L and 455-740 $\mu \mathrm{S} /$ $\mathrm{cm}),(3-89 \mathrm{CU}),(0.259-7.98 \mathrm{NTU}),(0-28.3 \mathrm{mg} / \mathrm{L}),(0.005-0.116$ $\left.\mathrm{cm}^{-1}\right),(0-20.65 \mathrm{mg} / \mathrm{L}),(6.99-11.04 \mathrm{mg} / \mathrm{L}),(<3-23 \mathrm{MPN} / 100 \mathrm{~mL})$, $(<3-9 \mathrm{MPN} / 100 \mathrm{~mL})$. Natural water Pond $(601 \mathrm{mg} / \mathrm{L}$ and $1001 \mu \mathrm{S} /$ $\mathrm{cm}),(532 \mathrm{CU}),(70.5 \mathrm{NTU}),(37.79 \mathrm{mg} / \mathrm{L}),\left(0.605 \mathrm{~cm}^{-1}\right),(22.41$ $\mathrm{mg} / \mathrm{L}),(16.49 \mathrm{mg} / \mathrm{L}),(43 \mathrm{MPN} / 100 \mathrm{~mL}),(43 \mathrm{MPN} / 100 \mathrm{~mL})$. 


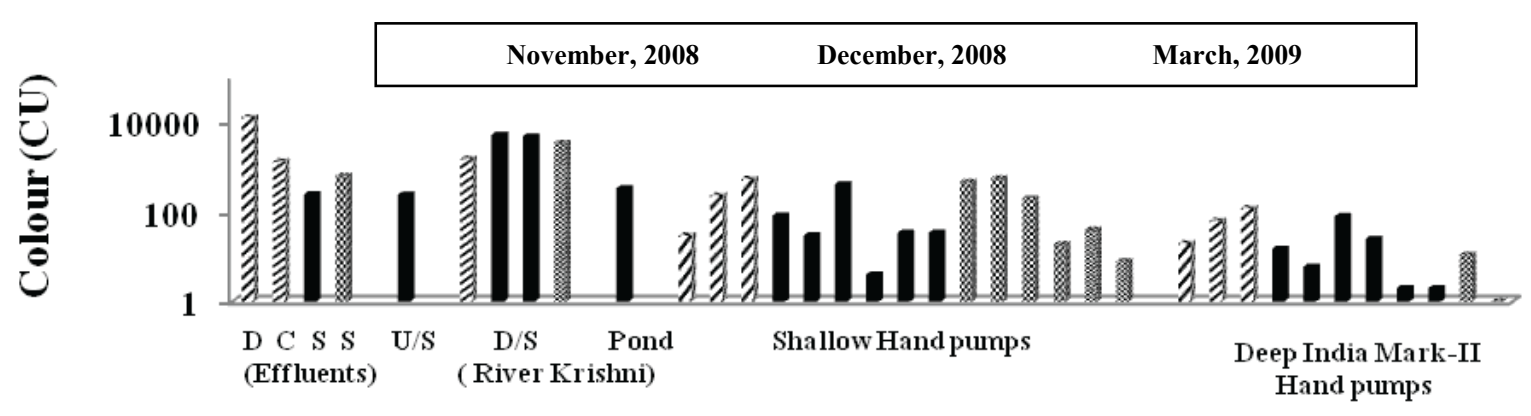

Figure 3. Spatial and temporal variation of colour (Nov. 2008 - Mar. 2009).

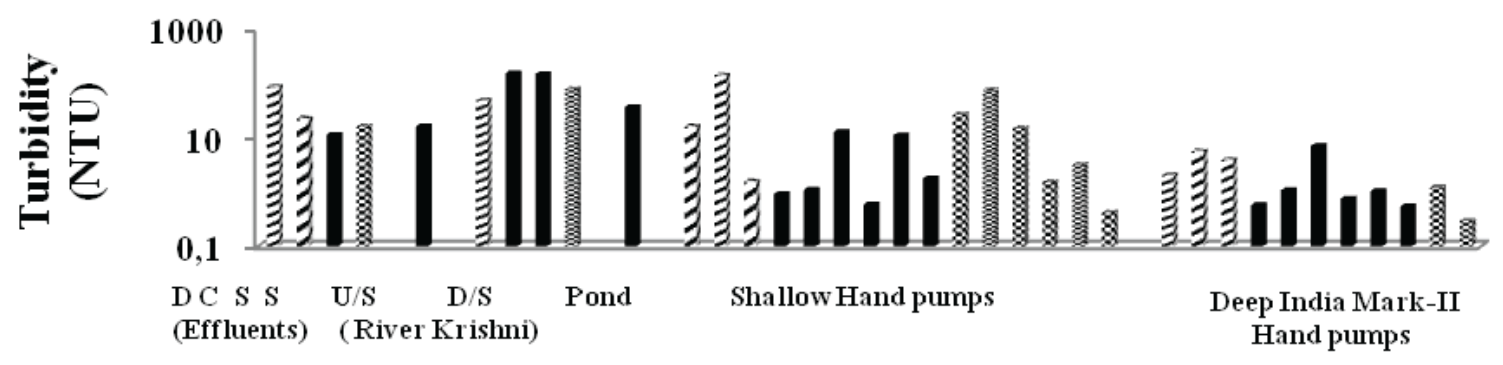

Figure 4. Spatial and temporal variation of turbidity (Nov. 2008 - Mar. 2009).

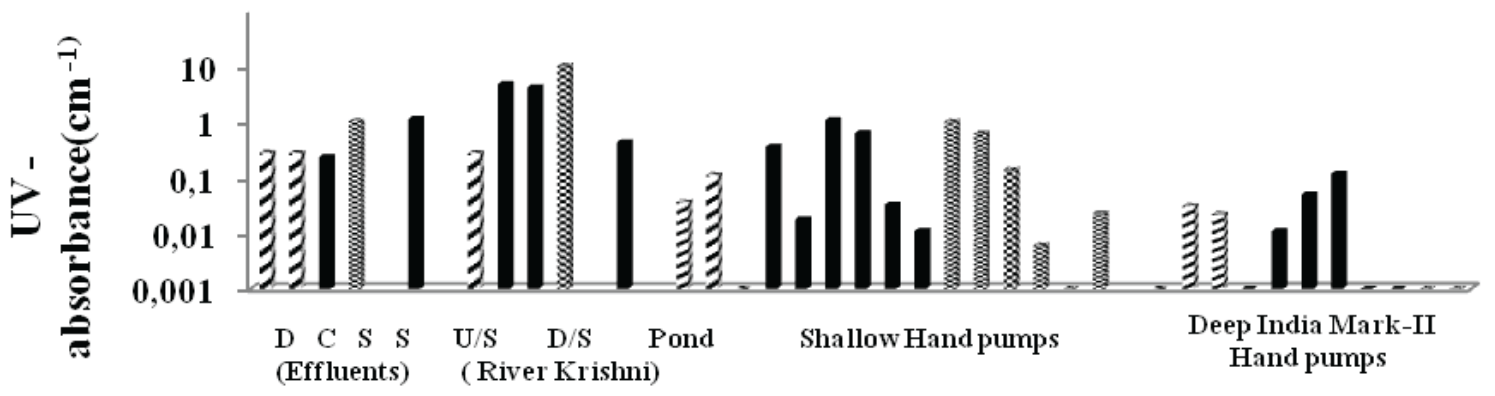

Figure 5. Spatial and temporal variation of UV- absorbance (Nov. 2008 - Mar. 2009).

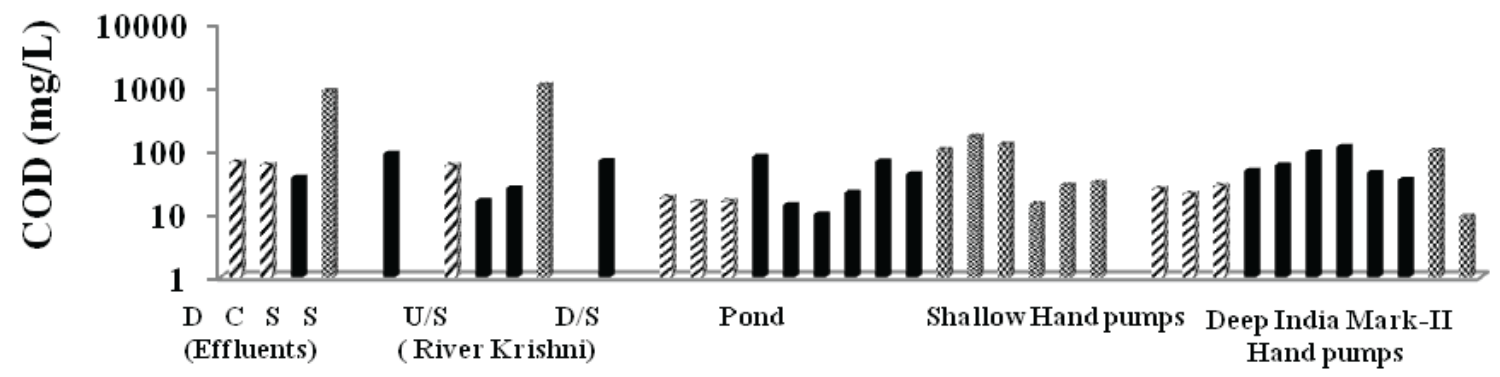

Figure 6. Spatial and temporal variation of COD (Nov. 2008 - Mar. 2009).

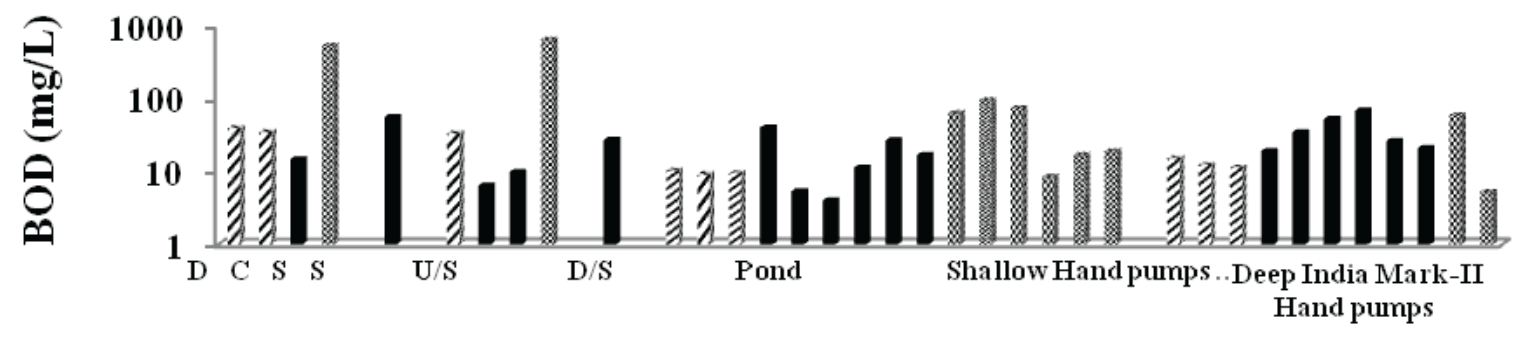

Figure 7. Spatial and temporal variation of BOD (Nov. 2008 - Mar. 2009). 


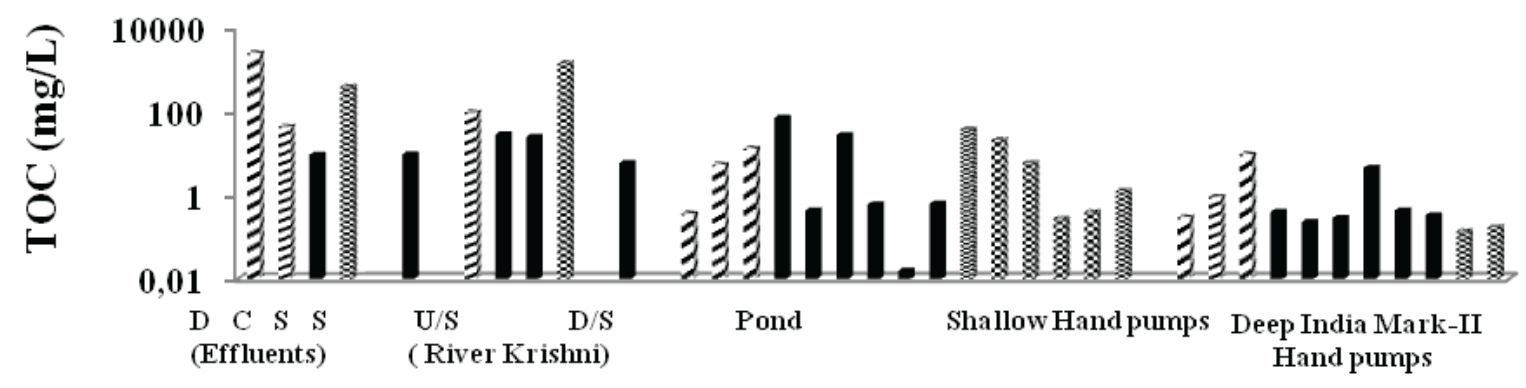

Figure 8. Spatial and temporal variation of TOC (Nov. 2008 - Mar. 2009).

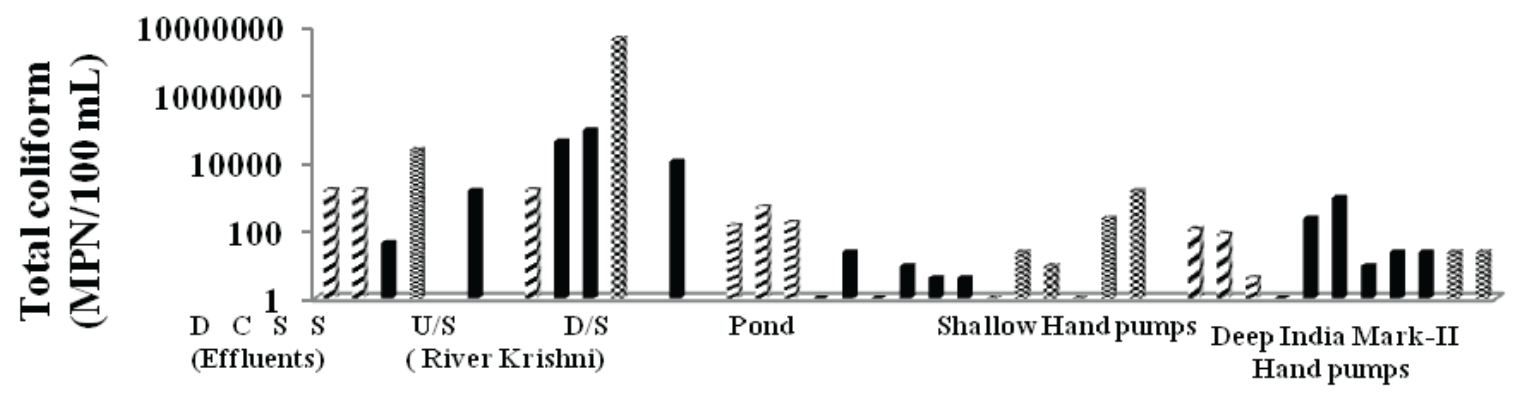

Figure 9. Spatial and temporal variation of total coliform (Nov. 2008 - Mar. 2009).

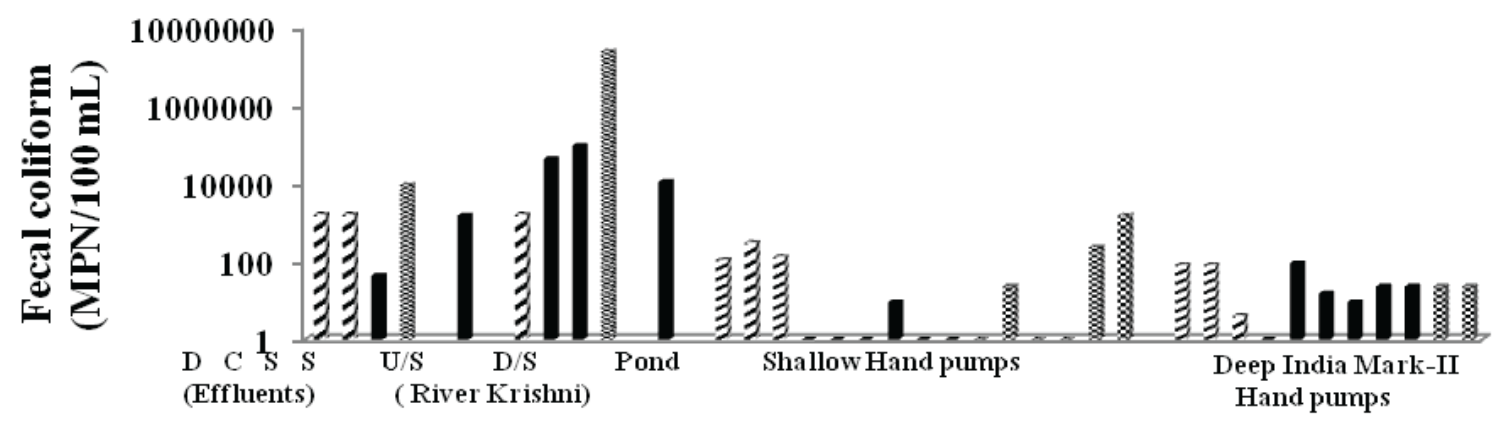

Figure 10. Spatial and temporal variation of fecal coliform (Nov. 2008 - Mar. 2009).

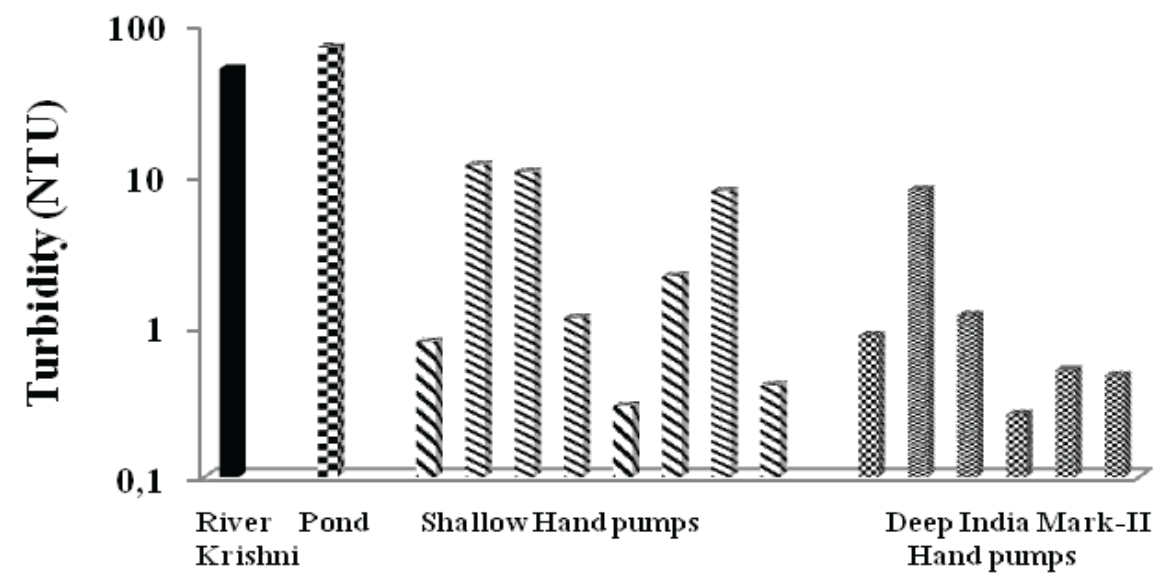

Figure 11. Spatial variation of turbidity (May, 2009). 


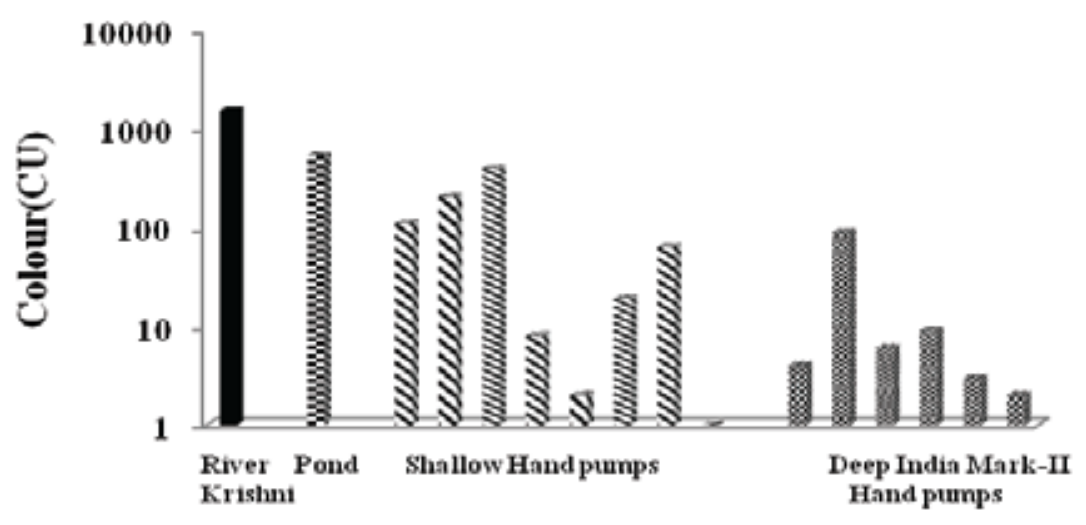

Figure 12. Spatial variation of colour (May, 2009).

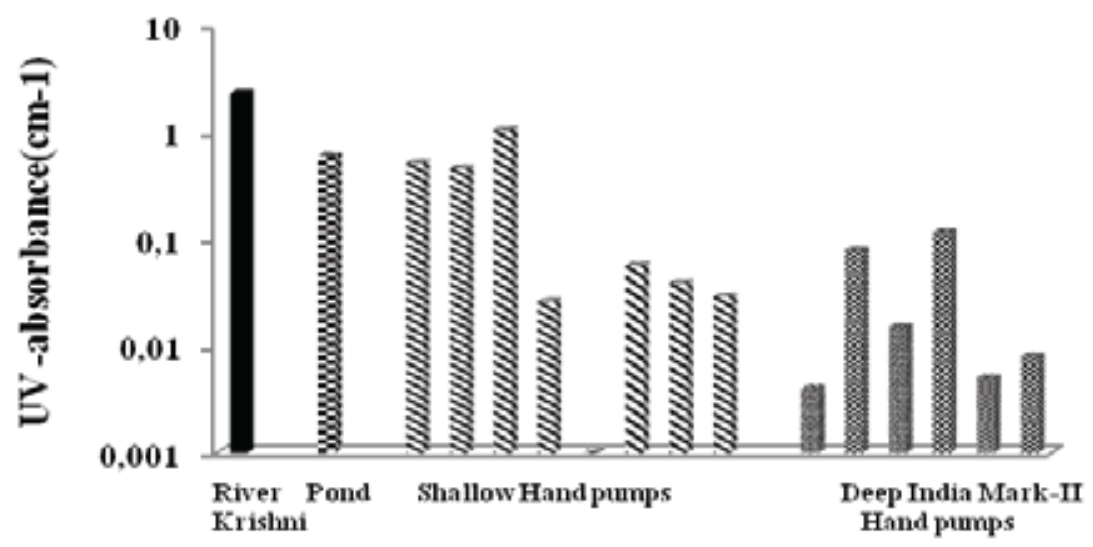

Figure 13. Spatial variation of turbidity (May, 2009).

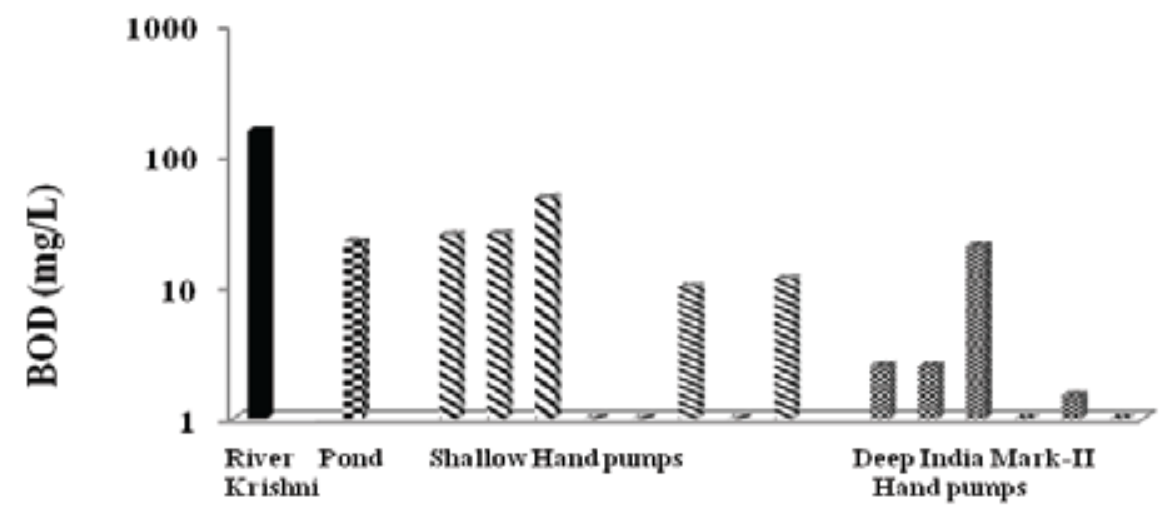

Figure 14. Spatial variation of turbidity (May, 2009).

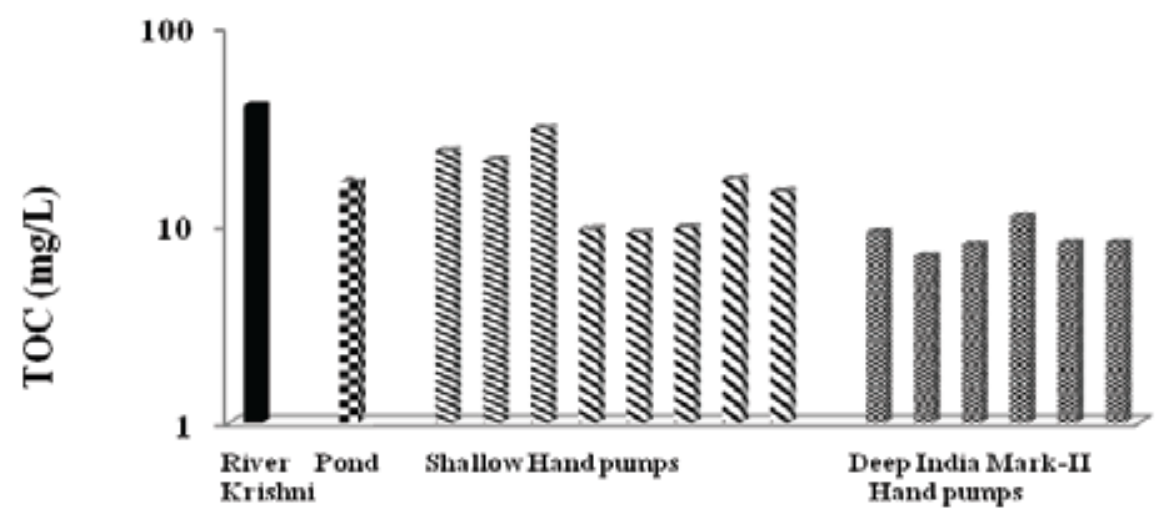

Figure 15. Spatial variation of COD (May, 2009). 


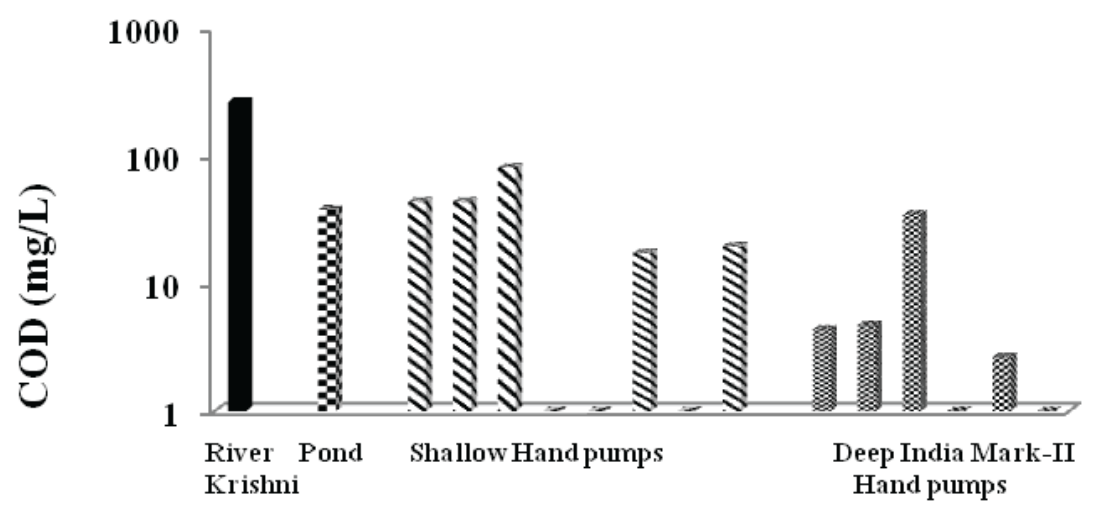

Figure 16. Spatial variation of TOC ((May, 2009).

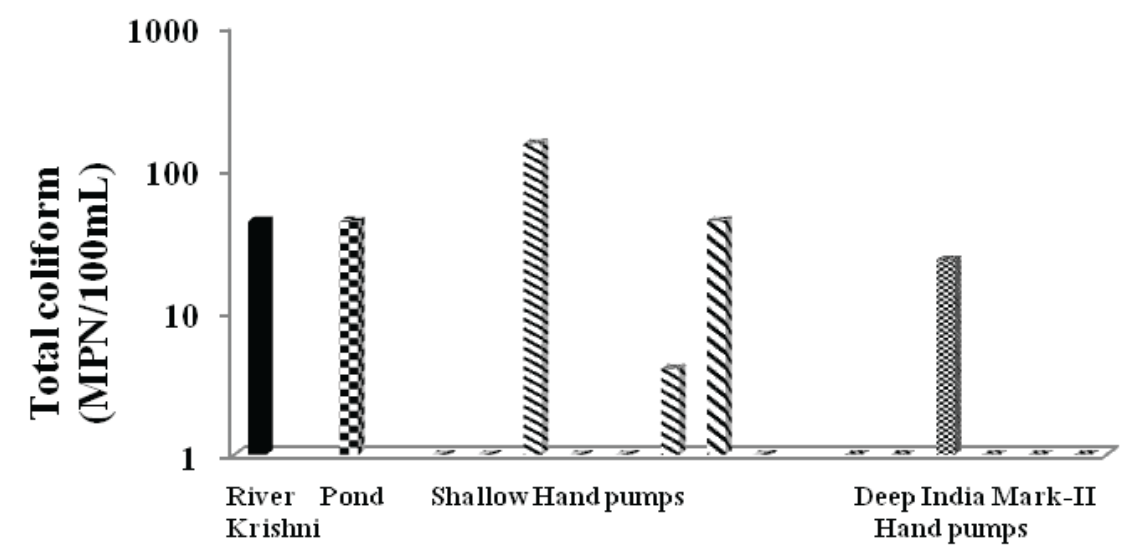

Figure 17. Spatial variation of total coliform (May, 2009).

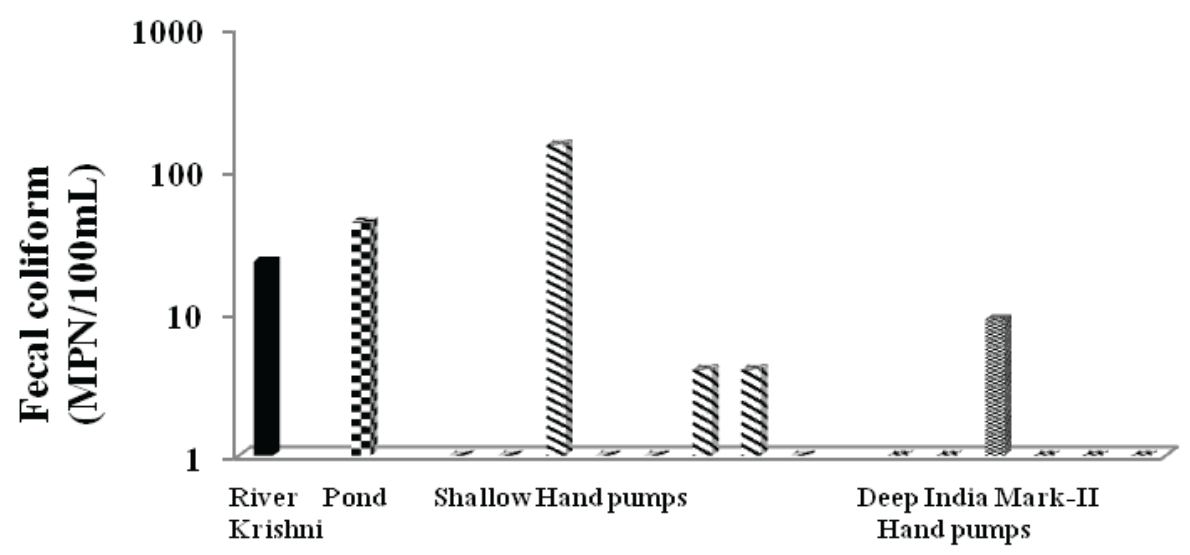

Figure 18. Spatial variation of fecal coliform (May, 2009). 
Table 2. Water Quality Parameters: Phase -2 (When Industries were not working)

\begin{tabular}{|c|c|c|c|c|c|}
\hline S.No & Parameters & River & $\begin{array}{c}\text { SHPs } \\
\text { (min. - max.) }\end{array}$ & $\begin{array}{l}\text { IM - II HPs } \\
\text { (min. - max.) }\end{array}$ & $\begin{array}{c}\text { Natural } \\
\text { Water pond }\end{array}$ \\
\hline 1 & $\mathrm{pH}$ & 7.42 & $7.21-8.1$ & $7.6-8.3$ & 8.47 \\
\hline 2 & $\begin{array}{l}\text { Conductivity } \\
(\mu \mathrm{S} / \mathrm{cm})\end{array}$ & 2160 & $455-1528$ & $455-740$ & 1001 \\
\hline 3 & TDS (mg/L) & 1296 & $273-971$ & $273-444$ & 601 \\
\hline 4 & $\begin{array}{l}\text { Turbidity } \\
\text { (NTU) }\end{array}$ & 50.8 & $0.294-11.7$ & $0.259-7.98$ & 70.5 \\
\hline 5 & Colour (CU) & 1520 & $01-395$ & $3-89$ & 532 \\
\hline 6 & TOC (mg/L) & 40.09 & $9.143-30.65$ & $6.99-11.04$ & 16.49 \\
\hline 7 & $\begin{array}{l}\text { UV-absorbance } \\
\left(\mathrm{cm}^{-1}\right)\end{array}$ & 2.301 & $0.001-1.053$ & $0.005-0.116$ & 0.605 \\
\hline 8 & $\mathrm{COD}(\mathrm{mg} / \mathrm{L})$ & 265.94 & $3.23-26.6$ & $0.0-28.3$ & 37.79 \\
\hline 9 & $\mathrm{BOD}(\mathrm{mg} / \mathrm{L})$ & 157.94 & $0.0-48.25$ & $0.0-20.65$ & 22.41 \\
\hline 10 & $\begin{array}{l}\text { Total hardness } \\
(\mathrm{mg} / \mathrm{L})\end{array}$ & 336 & $256-772$ & $324-472$ & 288 \\
\hline 11 & $\begin{array}{l}\text { Total coliform } \\
\text { (MPN/100mL) }\end{array}$ & 43 & $<3-150$ & $<3-23$ & 43 \\
\hline 12 & $\begin{array}{l}\text { Fecal coliform } \\
\text { (MPN/100mL) }\end{array}$ & 23 & $<3-150$ & $<3-9$ & 43 \\
\hline
\end{tabular}

SHP -Shallow Hand pump; IM-II HP - India Mark-II Hand pump

\section{Conclusion}

The objective was to study effect of pollution in River Krishni on the quality of ground water abstracted through shallow and deep hand pumps placed in the close vicinity of River Krishni. Assessment of the river water and water from hand-pump(s) was carried out at village Chanedna Maal.

Hand pumps abstracting ground water from shallow as well as deeper aquifers have been found to deliver polluted water in terms of color, organics and presence of coliform bacteria. Ground water at Village Chanedna Maal appears to be heavily polluted due to the pollution in River Krishni caused by the effluents from industries. To overcome the problem, a tube well has been constructed which is expected to start functioning by December, 2009. There is a need to study/check the quality of tube well water.

\section{References}

1. Sahu, V. P., (1993), Pollution study of river Ganga at Kanpur and Farrukhabad using water quality indices, M.E. Dissertation (unpublished), Environmental Engineering Division, Department of Civil Engineering, University of Roorkee.

2. Jitin, K., (2002), Evaluations of ground water quality: laboratory studies, M.Tech Dissertation (unpublished), Environmental Engineering Division, Department of Civil Engineering, IIT Roorkee.

3. Gupta, S., Deswal, S., Kumar, D. and Das, G., (2009), Assessment of water quality in the Villages of Ambala District, Haryana (India). Proceedings of International conference on Energy and Environment, March 19-21, 2009; ISSN: 2070-3740.

4. Doussan, C., Poitevin, G., Ledoux, E., and Detay, M., (1997), River bank filtration: Modeling of the changes in water chemistry with emphasis on nitrogen species. J. Contam. Hy-drol., 25:129.

5. Dash, R. R., Mehrotra, I., Kumar, P., and Grischek, T., (2008), Lake bank filtration at Nainital, India: water-quality evaluation. Hydrogeology Journal, 27 February 2008.

6. Kumar. N. and Sharma, R. C., (2002), Water quality of river Krishni part-1. Physcio-chemical characteristics, Journal of nature conservation
2002 vol.14 (no.2)

7. Ibe Sr, K. M., and Egereounu, U. U., and Sowa, H.O., (2001), The impacts of hand pump corrosion on water quality in rural area of West African sub-region. Department of Geology, Federal University of Technology, Owerri, Nigeria.

8. Jal Nigam, Muzaffar Nagar District, (2008), Water supply scheme project report- based on a deep tube $\mathrm{w}$ ell in village Chandena Mall. U.P. India.

9. Standards method for the examination of water and wastewater, (2005) $19^{\text {th }}$ Edition, prepared and published jointly by APHA, AWWA and WEF, Washington, DC 20001-3710.

10. Ahmed, I., and Umar. R., (2008), Hydrogeological framework and water balance studies in parts of Krishni-Yamuna interstream area, Western Uttar Pradesh, India. Environ Geology 53:1723-1730.

11. Bhatnagar N. C., Agashe R. M., Mishra A. K. (1982), Subsurface mapping of aquifer system, water balance study of Upper Yamuna Basin, Section-Hydrogeology, technical report No. 2, CGWB, NW region, Chandigarh. 